\title{
Samuel Beckett's Waiting for Godot: A Postmodernist Study
}

\author{
Noorbakhsh Hooti (corresponding author) \\ Razi University, Faculty of Arts, English Department, Kermanshah, Iran, \\ Tel: 98-912-593-5460Ｅ-mail: nhooti@yahoo.com \\ Pouria Torkamaneh \\ Razi University, Faculty of Arts, English Department, Kermanshah, Iran, \\ Tel: 98-936-190-1411 E-mail: pouriatorkamaneh@yahoo.com
}

Received: May 3, 2011 Accepted: May 23, 2011 doi:10.5539/ells.v1n1p40

\begin{abstract}
This study tends to delve into the different facets of the play Waiting for Godot on a postmodern bedrock, where the role of modernism cannot be disavowed. Waiting for Godot shares both modernist and postmodernist features. Nullification of linear historical time, imprisonment within an ahistorical prospect, predisposition toward the perception of uncertainty or the notion of 50/50 chances, evincing numerous signs of binary opposition and most important of all displaying absolute absurdism in all parts of the play have paved the path to give it a postmodern scrutiny.
\end{abstract}

Keywords: Godot, Nihilism, Postmodernism, Modernism, Binary opposition

\section{Introduction}

It is so hard to live your life knowing the person you want to be with for the rest of your life never actually notices you. Hoping that someone might notice you, wishing that this person feels the same one of these days, can be so hard to cope with. How long can we be hopeful? How long does a believer have to wait? Everyone is waiting for that somehow, someday. But why does it have to be this way? Why does every time we wait for somebody or something we mostly fail...? Maybe we fall in the trap of waiting; a waiting that has no solution except keeping on waiting.

This study begins with a prelude to postmodernism, which is followed by a concise look at Waiting for Godot, and finally the play will be analyzed on postmodern bedrock.

\subsection{Postmodernism}

Modernity and postmodernity are epochs posited in a quite common, although by no means universal, philosophy of history, as Lyotard asserts that "although the dates of preiodisation, a popular version identifies modernity as the period from Enlightenment to the mid twentieth century, and postmodernity as after that". (1984, p. 3)

The term postmodernism is still the subject of heated debates. It clearly succeeds modernism, a term which was prevalent as an international movement during the 1900s, a term which had two bloody World Wars under its shelter. Indeed these two devastating wars led to the everlasting question of the validity and eligibility of the Rationality in general and Modernism in particular. Actually postmodernism is a dramatic deviation of man's thought line; it is a renaissance towards breaking the fossilized shackles of the prescribed norms and notions, which have changed into economic and political institutions. These prescribed and unchanging beliefs are the trump cards of the power-maniac figures, who utilize them in expediency to rationalize and legitimize their brutality and unjust justice.

The phenomenon of postmodernism cannot be enunciated in purely temporal words. It somehow shackles most of the obvious epistemological points in various scientific points. In postmodernism, unlike modernism, we are not dealing with any scientific rules, but it is the absolute incredulity toward Metanarrative, which became popular, mostly after the Second World War. It postulates working without rules in order to formulate the rules of what will have been done and this is something quite ordinary in Beckett's works. Each one starts anew, inventing its own rules as it goes along.

Postmodernism relies heavily on fragmentation, paradox and questionable narrators. It puts science and technology at bay. It refers to the state that lacks a central hierarchy. According to Hooti \& Azizpour (2010, p.15):

"Postmodernism" is used to describe a wide gamut of aesthetic, cultural, historical, literary, and philosophical 
goings-on. It is often also used to suggest, variously, an eclectic style, a historical period, and a philosophical concept, as well as an anti-style, an atemporal event, and a non-concept. Often associated with deconstruction and poststructuralism, it is a term which undergoes uninterrupted redefinitions. In the visual arts and in architecture, postmodernism is referred as pastiche or eclecticism. In philosophy, it stands against defining logocentrism and epistemological certainty that has characterized Western philosophy since Descartes.

In postmodernism nothing is based on logical reasoning. Nothing is framed within a presupposed universal truth. In the 21 st century everyone has lost faith in a perfectly ordered, rational universe. The world is a place where things happen randomly. You live or you die by chance. The conditions you endure, you endure by chance. There is no well-crafted plan, no scheme of justice in most parts of the world by which the universe operates.

In postmodernism you cannot find any certainties in any section of the universe and everything has been brought into question. The postmodernity tends towards elaboration, eclecticism, ornamentation and inclusiveness. It dismisses the existence of an absolute reality and is deeply suspicious of the concept of human progress. As a matter of fact, it is a new era of endeavor whose activities are unclear and whose meanings and implications are not yet well understood. Thus, postmodernism is characterized by insecurity, uncertainty and skepticism. As Hooti (2011, p. 330) asserts:

Postmodernism is a comprehensive concept which has been challenged and argued over in so many scientific, literary, philosophical, cultural fields. Some critics regard it as originating in architecture. Based on natural attributes, it cannot be defined as stable and fixed.

The postmodern world is shaped by pluralism, democracy, religious freedom, consumerism, mobility and increasing access to news and entertainment. Residents of this world are able to see that there are many beliefs, multiple realities and an exhilarating, but daunting profusion of world views, a society that has lost its faith in absolute truth in which people have to choose what to believe.

Sometimes the characteristics of postmodernism are brought into question, but it is quite crucial to point that the features of postmodernism cannot be put into a specified category or box. Its beliefs and characteristics are well beyond any particular establishments; instead they are somehow more personal. Here are some elemental notions of postmodernism:

(1).There exists no absolute truth. As a matter of fact, truth is viewed as an illusion, abused by those who want to gain control over others.

(2).Truth and fallacy are synonyms. Facts and falsehoods can be used interchangeably and what is right today may appear to be wrong tomorrow.

(3).Traditional thinking and rationality are absolutely spurned by postmodernism. There is no determined rule to designate rationality or irrationality. It is all just up to the people's standpoint.

(4).Morality is personal. In general postmodernists subject morality to personal opinion. They define morality as to be followed by each person's code of ethics, rather than any secular or traditional rules.

(5).Modernism considered the fragmented view of the human life as bad or tragic; however, postmodernists rather celebrate this seemingly meaningless view of the world.

(6).Disillusionment with modernism- postmodernists rue the unfulfilled promises of the science, technology, government and religion.

\subsection{Literature and Postmodernism}

Postmodernism is a phenomenon of vast interpretation and focuses on so many aspects. In different fields including literature, philosophy, social sciences, arts, and so on what it tries to do is the portrait of all the artifacts as Human constructs. Though postmodernism was not born in the mind of literary critics, literature is one of the best ground in which postmodernism can be represented. In the postmodernism literature the boundary between fact and fiction is often dissolved. There is no boundary between fiction and reality; therefore, there is nothing absolute or eternal. Postmodern literature during 1960 to 1990 was the dominated mode in the literary works. Some features of postmodern literature are: ambiguity, complexity, decenterment, fragmentation in dialogue, pastiche, irony, parody, black humor, and allegory.

Although postmodernism has influenced all the literary forms, but usually it focuses on one kind of writing which mostly is narrative fiction. The narrative advances in flash backs, flash forwards and is frequently interrupted; it is like cinema and movie techniques. Beside the stupidity of war, another subject in postmodernism is ethnicity. It is about marginal groups: common man, black people and race and gender. Also it focuses on cultural aspects. Another concern of postmodern literature is the exploitation of human beings, especially woman and feminist issues. 
Feminism has developed its own criticism of the legal and ethical implications from postmodernism.

It is necessary to emphasize that postmodernist literature is not nihilistic or devoid of values, but it attacks injustices. However postmodern literature wishes to be free from conventions and traditional attachments.

Most important scientific concept for postmodernism is borrowed from Quantum Mechanics and Einstein relativity. Therefore multiple readings are possible, desirable, and even necessary. The postmodern sublime is present of unpresentable. This view attacks modernist sublime which says: there are some concepts which are unpresentable, therefore, it is the moment of failure because in modernism unpresentable cannot be present. One of the clearest definitions of postmodernism has been presented by Lyotard as follows:

The postmodern would be that which in the modern invokes the unpresentable in presentation itself, that which refuses the consolation of correct forms, refuses the consensus of taste permitting a common experience of nostalgia for the impossible, and inquires into new presentations - not to take pleasure in them, but to better produce the feeling that is something unpresentable. (cited in Malpas, 2005, p. 49)

\section{Waiting for Godot}

"let's go" _"we can't" _ "why not" _ "we are waiting for Godot" _"ah" (Becket, 1956 p. 16-henceforth Becket).

With this disconsolate utterance, Samuel Beckett introduces the strange world of Waiting for Godot, a mystery that is wrapped in enigma. Before the elucidation of any literary criticisms, it would be indispensable to take a perfunctory look at the play. Waiting for Godot was first written in French version in 1949 and then translated into English in 1954 by its Irish writer. The two down-and-out men who wait expectantly to visit inscrutable Godot, have nothing significant to do with their lives, while waiting at a tree in the middle of nowhere doing every possible thing, even contemplating suicide, just to keep the dreadful silence at bay. Their waiting is interrupted by passing through of three other characters of the play, Pozzo and his subservient slave, Lucky, and the boy whose name was not mentioned, but seems to be the messenger of Godot.

Waiting for Godot had the most strikingly profound impact on everyone, which commenced the trend that became known as the "theater of absurd". More importantly Samuel Beckett made Waiting for Godot as the violation of the conventional drama and the direction of expressionism and surrealism experiment in drama and theater. Waiting for Godot was one of the most exceptional plays of the post-second world war era. Esslin calls it "one of the successes of the post-war theater" $(1980$, p. 3)

More importantly the play does not formally end when the boy, who is somehow the harbinger of dejection, keeps Vladimir abreast of the fact that Godot is not coming this evening. The play indeed begins with waiting for Godot and ends with waiting for Godot as well.

\subsection{Tragio-comic Elements in Waiting for Godot}

Although Waiting for Godot is said to be depressing, but as a matter of fact in different parts of the play the four characters fabricate different movements of humor in their mannerism and behavior. In other words, tragic and comic aspects of the play are amalgamated simultaneously. Most of the time, we can feel this helpless absurdity throughout the play.

Estragon: why don't we hang ourselves?

Vladimir: with what?

Estragon: you haven't got a bit of rope?

Vladimir: no

Estragon: then we can't

Vladimir: let's go

Estragon: oh, wait, there is my belt

Vladimir: it's too short

Estragon: you could hang on to my legs

Vladimir: and who would hang onto mine?

Estragon: true (Becket, p. 42)

Or even when his pants are fallen off his feet, he does not notice that, and Vladimir makes him aware of that.

The expression "nothing to be done" (p. 2) is reverberated in most of their dialogues; it prevalently tries to impose the notion of absurdity in people's life. In other words, they strike up a new conversation or terminate one with this 
tangible feeling.

The meaninglessness or absurdity in the play is absolutely tangible when Pozzo utters out these meaningful words:

Pozzo: (suddenly furious.) Have you not done tormenting me with your accursed time! It's abominable! When! When! One day, is that not enough for you, one day he went dumb, one day I went blind, one day we'll go deaf, one day we were born, one day we shall die, the same day, the same second, is that not enough for you? (Calmer.) They give birth astride of a grave, the light gleams an instant, then it is night once more. (He jerks the rope.) On! (p. 37)

It is not only trying to unravel the notion of absurdity of his life, that everything like becoming deaf and dumb affected them easily, but also it is trying to mention the absurdity of everyone's life when mundane matters are put at the central part of their lives. He is saying these strange expressions so downheartedly due to the fact that, he has realized the true nature of life and the eternal life.

\subsection{Truth and its Denial}

Samuel Beckett mostly involves himself and his works in the system of language in many of his plays like Waiting for Godot (1954), Endgame (1958), Not I (1974)... He tries to reform the nature of reality in his own way. The irony in his works is that, to speak is to exist, but so as to speak one must utilize the system of language and words, which have no intrinsic meaning. In most of his works "truth" is somehow closed off from the reader. Also we can make it more elaborated by mentioning the fact that Deconstruction, a term which was first applied by the French philosopher Jacques Derrida (1930-2004), implicitly questions the validity of the hidden structure upon which other "truths" lie, a chain of truths that are linked together and this concept can be somehow attached to Beckett's works. White (2009, p. 1) aptly comments on Beckett, as he says "He is, however, a writer who confronts the realities of existence through a language that he himself deems to be ultimately ineffectual". He further comments that "everything in Beckett's world appears to be in decline and this erosion affects the characters physically and emotionally". (p.2)

Vladimir: "our saviour. Two thieves. One is supposed to have been saved and the other...damned" (Becket, p.5). Vladimir makes this point that even things which many consider to be true are subject to doubt. Beliefs are without rationality in waiting for Godot.

Beckett's outlook of postmodern life can be viewed as somehow bleak, helplessly hopeless and ironic where language does not have a certain meaning. Waiting for Godot illustrates the desire to prove one's existence and make sense of the world. Estragon and Vladimir have only one proved language in order to talk or communicate to one another and demonstrate each other's existence in that hopeless world; however, language is an inadequate system in reaching any abstract truth and more important than that, a word is only a representation of a truth, not the truth itself. Therefore we can imply that, the denial of the truth stems from the fact that there is no absolute truth in the world and also it is not too inapt to cast doubt on the absolute itself too, but still we draw our own subjective picture of truth in order not to get ourselves trapped in the mysterious complexities of the world around us. As Luntley (2003, p. 107) asserts:

This simple and commonsensical concept of truth is central to all our actions. Of course, this is not to say that we have the truth in all our actions. Rather it is to say that it is impossible to make sense of our lives without the idea that things happen independently of our thinking about them. We do not need to concentrate on science and the physical world to see that this is so.

As it is implied in the play, the only usage of communication is just to prove their existence as Estragon says: "we always find something, eh Didi, to give us the impression we exist" (p. 14)

\subsection{Uncertainty}

Although works of the theater of the absurd, particularly Beckett's, are often comical, their underlying premises are wholly serious, as Hutchings declares, "the epistemological principle of uncertainty and the inability in the modern age to find a coherent system of meaning, order, or purpose by which to understand our existence and by which to live" (1991, p. 28).

The other remarkable feature of uncertainty is that no one tries to make any movements. Estragon: "don't let's do anything. It's safer" (Becket, p.11) or "nothing happens, nobody comes, nobody goes, it's awful" (p.27). Due to their uncertainty, they are somehow afraid of making any movements, so they remain still, or when Vladimir says "Nothing is certain when we are about" (p. 8).

Even the most fundamental things are not certain, in other words, nothing is certain, not even sickness and death:

Estragon: Wait! (He moves away from Vladimir.) I sometimes wonder if we wouldn't have been better off alone, each one for himself. (He crosses the stage and sits down on the mound.) We weren't made for the same road. 
Vladimir: (Without anger) It's not certain.

Estragon: No, nothing is certain. (p. 45)

Another symbol of uncertainty is the lightening. The only lightening effect is when days turn rapidly to night and the moon rises. The surrealistic effect of this heightened change from day to night amplifies the theme of uncertainty. It should also be mentioned that, this play was written after the Second World War, when the insecurity about the Soviet Union was the order of the day as the arms race gave rise to the possibility of nuclear war.

Something which was never mentioned in the play, and can be taken into consideration is the characters' age. The humorous part is that, though it is not present as any dialogue, but it can be regarded as one of the points of uncertainty. Even when pozzo asks Vladimir about his age he does not respond, because he is not sure."PozzoYou are severe. (To Vladimir.) What age are you, if it's not a rude question? (Silence.) Sixty? Seventy? (To Estragon.) What age would you say he was? Estragon: Eleven.” (p. 21)

But apart from all these points of uncertainty, even there is no sense of certainty in Godot's entry time. In act one, when Estragon and Vladimir are talking about the Godot's time of arrival, they do not even have the slightest certainty of when he appears:

Vladimir: He said Saturday. (Pause.) I think.

Estragon: You think.

Vladimir: I must have made a note of it. (He fumbles in his pockets, bursting with miscellaneous rubbish.)

Estragon: (very insidious). But what Saturday? And is it Saturday? Is it not rather Sunday? (Pause.) Or Monday? (Pause.) Or Friday?

Vladimir: (looking wildly about him, as though the date was inscribed in the landscape). It's not possible!

Estragon: Or Thursday? (p. 8)

The most helplessly humorous part of this uncertainty is that they do not even know whether the person they are waiting for is named Godot or not as Vladimir says:Vladimir: To Godot? Tied to Godot! What an idea! No question of it. (Pause.) For the moment. Estragon: His name is Godot? Vladimir: I think so. (p. 14)

But other than this, Who Is Godot? When does he come? Where does he show up? Why does he have to come? Or even the most fundamental question: Why do they have to wait for Godot?

It is not only about Estragon and Vladimir, but also about humankind who helplessly in each segment of life waits for a new Godot. We are searching for the meaning of life too repetitiously and without purpose, always trying to find somebody or something that can take the lead of our lives. This postmodern world comes into being, when salvation is expected from an external entity.

\subsection{Helpless hope}

Although it has been asserted in many interpretations of the play that there is not even a shade of hope in it, but in certain parts of the play we can feel that the existence of hope is oscillating in it. As Vladimir puts it "I am glad to see you back. I thought you were gone forever". (p. 2)

While they are in absolute boredom of the despondent life, they have not lost their hopes or dreams as in:

Vladimir: do you remember the Gospel?

Estragon: I remember the maps of the holy land. colored they were. Very pretty. The Dead Sea was pale blue .the very look of it made me thirsty. That's where we'll go, I used to say, that's where we'll go for our honeymoon. we'll swim. We'll be happy. (p. 4)

However hope is sometimes felt substantially from the play, but hopelessness or deep gloom can be felt as well. When Pozzo's autocratic style or behavior toward his submissive slave, Lucky, especially when his arrival is displayed in act 1, indeed causes this sympathetic feeling in the onlooker's heart when he ties a person to neck and adjures him in the cruelest way. Moreover, this despairing feeling is intensified when Estragon and Vladimir take this tyrannical person for somebody else, as the person who is going to help them or save them, although that savior is called Godot.

Pozzo: (off). On! (Crack of whip. Pozzo appears. They cross the stage. Lucky passes before Vladimir and Estragon and exit. Pozzo at the sight of Vladimir and Estragon stops short. The rope tautens. Pozzo jerks at it violently.) back!

Noise of Lucky falling with all his baggage. Vladimir and Estragon turn towards him, half wishing half fearing to go to his assistance. Vladimir takes a step towards Lucky, Estragon holds him back by the sleeve. (p.15) 
Or even when Estragon and Vladimir want to know why lucky never puts down his bags, Pozzo says that he wants to get rid of him, therefore he is trying to somehow wheedle him not to leave him alone. It is not only about Lucky who is trying so hard to coax his master to keep him, but also the sad story about the human being who is sometimes taken advantage of by those who have gained control over them everlastingly and are entangled in their master's orders, so that, they cannot become a normal human being again forever.

One of the most essential and praiseworthy parts to be considered is the fact that, with all these desperate incidents they come across during their waiting, they never leave each other alone. Even when they do, they find each other again and regret having left each other alone. Indeed they never decide to leave each other in the lurch. In their journey of life, uncertainties and obstacles push them toward failure and unhappiness, and although they pass each other derogatory words most of the time, but still they find each other's existence as a sparkling point of hope. As this dialogue can prove the claim "Estragon: (wild gestures, incoherent words. Finally.) Why will you never let me sleep? Vladimir: I felt lonely. (p. 37)"

One of the most spectacular but mystifying part of this play is Lucky's speech in act one.

Given the existence as uttered forth in the public works of Puncher and Wattmann of a personal God quaquaquaqua with white beard quaquaquaqua outside time without extension who from the heights of divine apathia divine athambia divine aphasia loves us dearly with some exceptions for reasons unknown but time will tell and suffers like the divine Miranda with those who for reasons unknown but time will tell are plunged in torment plunged in fire whose fire flames if that continues and who can doubt it will fire the firmament that is to say blast hell to heaven so blue still and calm so calm with a calm which even though intermittent is better than nothing but not so fast and considering what is more that as a result of the labors left unfinished..."(p. 34)

It is definitely one of the parts that conveys a whole lot of extraordinary ideas. He is speaking endlessly and clamorously in a way that the other characters are suffering from his monologue. No one can figure out what he really means by those strange words. Words like "belcher, testew, cunard, or apathia" are somehow hard to understand, but somehow it can be implied that he is talking about God or his existence or even when mentions that God has white beard. It can be construed as :Acknowledging the existence of a personal God, one who exists outside time and who loves us dearly and who suffers with those who are plunged into torment, it is established beyond all doubt that man for reason unknown, has left his labors, abandoned and unfinished. It is just a simple definition for those readers or audiences who are trying to decode this monologue, although here may be more to it than meets the eyes.

Faith in future is obvious not only from the dialogues, but it can also discernibly be grasped from the tree which was dead in act 1, while it bloomed in the second act, Though only four or five leaves were visible on the tree. The most pivotal part of the play is; however, they are kept posted by the boy that Godot is not coming this evening either, they acquiesce reluctantly to go far away, but neither of them leaves the stage or at least it is supposed that nobody moves. Therefore, it showed the same fluctuating hope which can be insinuated as a kind of hopeless hope in a helpless manner.

But apart from all these mindboggling points, absence of Godot, should not be neglected. Who Is Godot? When does he come? Where does he show up? Why does he have to come? Or even the most fundamental question: Why do they have to wait for Godot? The question of Godot's identity does more than tantalizing spectators of Beckett's play. It is a paradigm of textual tantalization itself. Its answer appears to lie outside the play, encouraging criticism to return to that realm it once called home: the author's intentions. However, this ancient ground of textual meaning now seems abandoned, most explicitly in Beckett's work, where its vacancy is announced, paradoxically, in the form of a text strongly marked with intentionality: the direct nonfictional statement of authorial intent.

\subsection{Nihilism}

Nihilism is a radical philosophy of meaninglessness. The world and the people in it exist without meaning, purpose, truth and value. Any system of belief, or artistic expression, which denies or drains away meaning can be described as "nihilistic". According to Baudrillard, "today's nihilism is one of transparency, a nihilism that is a major source of indifference" (quoted in Dicken, 2009, p. 42). Thus the 'transpolitical' order of the contemporary society is characterized by the "disappearance, of the real, of meaning, of the individual, of the social and so on" (ibid). When everything becomes political, politics disappear; when everything becomes sexual, sex disappears; when everything is social, the social disappears...

Postmodernism as a state of thought is often innocently accused of being nihilistic and postmodernity is often seen as a nihilistic state of society. Levin (2001, p. 5) aptly asserts that:

The modern epoch brought into being a world in which the effects of nihilism are spreading. Now, we can see, today, 
if we look with care and thought, that nihilism is a rage against Being: 'nihilism' means the destruction of Being: the Being of all beings, including that way of being which we call 'human' and consider to be our own. Thus, in the postmodern situation, we need to achieve, both individually and collectively, a recollection of Being, of its dimensionality. This is possible, however, only if the question of Being can become, for us, a question of character a question that questions the historical character of our vision.

Nihilism is the radical repudiation of values, meaning and desirability. As Nietzsche says: "Nihilistic thought has many related manifestations: ontological, epistemological, existential, political and moral" (1968, p.7). The common nihilistic debilitation is usually associated with moods of despair, random destructiveness and longing for nothingness.

In Waiting for Godot, the nihilistic atmosphere can be observed. Estragon and Vladimir, the two protagonists, thrust a lack of meaning and purpose upon the observer's soul. They often insist on chatting about meaningless matters in order just to kill the time. Beckett's use of nonsensical language exposes the existentialist theme throughout the whole play

As we go along the play, we come across with one of the Estragon's dialogues as he says, "Why don't we hang ourselves?" (Becket, p. 41) Even though their lives have turned to be so monotonous that they are inclined to hang themselves, it somehow implies something other than that. Nietzsche puts it better when he says: "suicide is the deed of nihilism" (1968, p. 143). Hence; it would not be inappropriate to declare that there is a very remarkable connection between waiting for Godot and nihilism which lies within postmodernism.

\subsection{Binary opposition}

Postmodern theories stand against all the predetermined, prescribed and fossilized norms and values which keep on lashing and leashing man and turning a blind eye and a deaf ear to his needs and expectations. The notions like black and white, dull and smart, beautiful and ugly....are the sad gifts of the world of modernism that torment the postmodern atmosphere.

Binary opposition is potently omnipresent in most of the writers' writings and it can be vividly observed in Beckett's Waiting for Godot, which highlights the lack of stability and coherence of the text as an exemplifier of a postmodern discourse. The following points can support the claim:

(1).The opposition between Vladimir and Estragon's actions, ways of thinking, feelings, appearance and even their levels of intelligence has created this extraordinarily magnificent appeal to the readers or observers' soul and mind. From the beginning of the play we can feel the philosophical manner

(2).of Vladimir's thinking, while Estragon is mostly obsessed with mundane matters. In other words estragon does not contemplate profoundly about different matters as in:

Vladimir: One out of four. Of the other three, two don't mention any thieves at all and the third says that both of them abused him.

Estragon: Who?

Vladimir: What?

Estragon: What's all this about? Abused who?

Vladimir: The Saviour.

Estragon: Why?

Vladimir: Because he wouldn't save them.

Estragon: From hell?

Vladimir: Imbecile! From death.

Estragon: I thought you said hell.

Vladimir: From death, from d ( pp. 5-6)

3. Although Estragon and Vladimir are negligent of the notion of time, but pozzo is very cautious and heedful about it. More accurately, they do not even find the spending of the time something worthy, passing the time is what they like, but pozzo keeps track of the time alertly:

Stop! (Lucky stops.) Yes, the road seems long when one journeys all alone for ... (he consults his watch) . . yes ... (he calculates) ... yes, six hours, that's right, six hours on end. (p. 17)

4. The irritating behavior of pozzo is another important symbol. While he orders Lucky intermittently, estragon calls 
him "Mr." and pozzo does nothing, but making fun of his way of addressing:

Estragon: Mister . . . excuses me, Mister ...

Pozzo: You're being spoken to, pig! Reply! (To Estragon) Try him again.

Estragon: Excuse me, Mister, the bones; you won't wanting the bones?

Lucky looks long at Estragon

Pozzo: (In raptures). Mister! (Lucky bows his head.) Reply! Do you want them or don't you? (Silence of Lucky. To Estragon.) (p. 20)

5. When they are so depressed with their monotonous life that they want to hang themselves, but it manifests their appearances which are the antithesis of one another.

Estragon: Let's hang ourselves immediately!

Vladimir: From a bough? (They go towards the tree.) I wouldn't trust it.

Estragon: We can always try.

Vladimir: Go ahead.

Estragon: After you.

Vladimir: No no, you first.

Estragon: Why me?

Vladimir: You're lighter than I am. (p.10)

6. One of the comic yet remarkable aspects of this play is forgetfulness of Estragon, while Vladimir remembers very little things vividly. In many different parts of the play, Estragon reminds his friend about the numerous things that he has forgotten:

Vladimir: Wait ... we embraced ... we were happy ... happy ... what do we do now that we're happy ... go on waiting ... waiting ... let me think ... it's coming ... go on waiting ... now that we're happy ... let me see ... ah! The tree!

Estragon: The tree?

Vladimir: Do you not remember?

Estragon: I'm tired.

Vladimir: Look at it. They look at the tree.

Estragon: I see nothing.

Vladimir: But yesterday evening it was all black and bare. And now it's covered with leaves.

Estragon: Leaves?

Vladimir: In a single night.

Estragon: It must be the Spring. (Becket, p. 10)

\subsection{Toward Delogocentrism}

Beckett's central characters in Waiting for Godot have created a logo called Godot, a logo, which seems to be the ultimate source of erasing the misery of the miserably helpless creatures who find themselves doomed and drowned in the oozy ocean of incapability. They do feel the vacuum of nothingness. Godot is the sole power, which is expected to save and enrich them and change their dystopia into utopia. By introducing such characters, Beckett wants to remind us of those people who seem to be simply moving and living creatures, but indeed lack the sense of existence in their lives. The sense of existence comes when there is the sense of self-esteem, the sense of ability of making decisions and changing one's own world and above all the sense of having the ability to think your own thoughts independently. Beckett's characters seem to be tied up to the logocentric term Godot and have taken it for granted that Godot is the dominant source of donation and salvation. They believe that the colorful meaning of truth can be only attained under the shelter of the presupposed logos. Actually such logos under different guises rule all such astray and thoughtless thinking creatures that lack self-esteem, self-confidence and above all self-determination. They find the sense of reality within the realm of their pre-assumed logos. The French philosopher Jacques Derrida is the one who has maneuvered enough on the logocentrism. As Hooti and Shooshtarian (2010, p. 151) comment:

Derrida, as one of those twenty-century philosophers who did research on the relationship between language and 
reality, in his texts, Writing and difference and Of Gramatology, denied the stability of signification system and the pre-supposed stability between them and in this way, he argued the validity of "logocentrism. According to Derrida, there is no pre-existent truth, "transcendental signifier or "logos" to which one can appeal to find meaning. His "deconstruction" as Ulmann maintains, "affirms the importance of ambivalence, of the relation between terms rather than the choice of one term over another.

\section{Conclusion}

The conclusion for many critics has seemed inescapable. As Nealon puts it, "Waiting for Godot is an attack on modernism with its ideological and Grand Narrative that claims to interpret the world Estragon and Vladimir are trapped by their modernist nostalgia for legitimation in Godot" (1992, p. 51).

To put it in a nutshell, we can allude that the stream of consciousness in the play implies that nothing "out there" defines or determines Estragon and Vladimir; instead it is their own actions and freewill, their own choices that are the most "fundamental to their existence". The enigmatic road, the cryptic tree and more importantly all the characters in it are not primarily meaningful, orderly or rational; instead they exist in a basically indifferent, objective, often ambiguous and "absurd" world and although meaning is not "out there", they try to create it in themselves.

Waiting for Godot is a poignant play about a ceaseless waiting, about repetition, the meaninglessness, the absurdity of waiting, of feeling (and being) suspended in time instead of moving forward in a meaningful direction and, about waiting for waiting and finally being imprisoned in one's mind. It is not necessarily about the absence of God, or about Christian salvation, or existential despair, or nihilistic meaninglessness, or postmodern critique of language, though interpretation is a subjective enterprise, we can interpret literature how we choose. And finally, one way of understanding this play is to see it as an abstract play about waiting, about waiting for the responsibility of a better future that we are not quite fully convinced will never arrive. As Hooti and Azizpour (2011, p. 21) comment:

Our postmodern world seems very likely to become one of spiritual emptiness and cultural superficiality, in which social practices are endlessly repeated and parodied, a fragmented world of alienated individuals with no sense of self or history, tuned into a thousand different TV channels. This is certainly the vision of both present and future offered to us by the postmodernist Jean Baudrillard. For him, this postmodern world is one of simulacra in which there is no longer any difference between reality and surface.

\section{References}

Becket, Samuel. (1956). Waiting for Godot. London: Faber.

Diken, Bülent. (2009). Nihilism. New York: Routledge.

Esslin, Martin. (1980). The Theater of Absurd. New York: Penguin books.

Hooti, Noorbakhsh \&Azizpour, Farzaneh. (2010). Arthur Miller's Death of a Salesman: A Postmodernist Study. Studies in Literature and Language, 8(1) 15-28.

Hooti, Noorbakhsh \&Azizpour, Farzaneh. (2011). The Sense of Isolation in Arthur Miller's All My Sons: A Postmodernist Study. Cross-cultural Communication, 7(1) 17-31.

Hooti, Noorbakhsh \& Shooshtarian, Samaneh. (2011).A Postmodernist Reading of Tom Stoppard's

"Rosencrantz and Guildenstern Are Dead". Studies in Literature and Language, 2 (1), 147-162.

Hooti, Noorbakhsh. (2011). Oscillation between Modernism to Postmodernism in Shakespeare's Hamlet. Theory and Practice in Language Studies, 4(1), 327-336.

Hutchings, William. (1991). Waiting for Godot and Principles of Uncertainty: Approaches to Teaching Samuel Beckett's Waiting for Godot. New York: MLA.

Levin, David Michael. (2001). The Opening of Vision: Nihilism and the Postmodern Situation. New York and London: Routledge.

Luntley, Michael. (2003). Reason, Truth and Self: the postmodern reconditioned. London \& New York: Taylor \& Francis.

Lyotard, Jean Francois. (1984). The Postmodern Condition: A Report on Knowledge, Geoff Bennington and Brian Massumi (Trans.). Minneapolis: University of Minnesota Press.

Malpas, Simon. (2005). The Postmodern: The New Critical Idiom. New York: Routledge.

Nealon, Jeffrey (1992). Samuel Beckett and Postmodernism: Language, Games, Play and Waiting for Godot and 
Endgame. London: Macmillan.

Niettzsche, Fredrich (1968) The Will Power. New York: Vintage.

White, Kathryn. (2009). Beckett and Decay. New York: Continuum International Publishing Group. 